\title{
PENGEMBANGAN BUKU SAKU INTENSIFIKASI BAHASA ARAB DI IAIN METRO DENGAN MENGGUNAKAN MODEL ADDIE
}

\author{
Nawang Wulandari \\ Institut Agama Islam Negeri (IAIN) Metro \\ Jl. Ki Hajar Dewantara 15A Iring Mulyo Kota Metro \\ darinawangwulan@gmail.com
}

\begin{abstract}
This study explains the steps of developing a teaching material product in the form of an Arabic Pocket Book which is fun for beginners. The development model used in this study is the development of ADDIE models. Needs Analysis until the evaluation is carried out as a reference for development. Validation of Material Experts, Media Experts and Learning Practitioners is used to determine the feasibility of the Pocket Book developed. Based on the results of the analysis using Analysis Variant (ANOVA), the data obtained shows that the mean in the class taught using the developed Pocket Book is greater than the Mean in the class taught using pre-existing books, namely 35.64 and 29.76, so it can concluded that the use of the Pocket Book gives a better influence.
\end{abstract}

Keywords: Development of ADDIE Model, Arabic Language

\section{Abstrak}

Penelitian ini menjelaskan langkah-langkah mengembangkan produk bahan ajar dalam bentuk Buku Saku Bahasa Arab. Model pengembangan yang digunakan dalam penelitian ini adalah pengembangan model ADDIE. Analisis Kebutuhan sampai evaluasi dilakukan sebagai langkah-langkah dalam pengembangan. Validasi Ahli Materi, Ahli Media dan Praktisi Pembelajaran digunakan untuk menentukan kelayakan Buku Saku yang dikembangkan. Berdasarkan hasil analisis menggunakan Analysis Variant (ANOVA), data yang diperoleh menunjukkan bahwa mean di kelas yang diajarkan menggunakan Pocket Book yang dikembangkan lebih besar dari Mean di kelas yang diajarkan menggunakan buku yang sudah ada, yaitu 35.64 dan 29.76, sehingga dapat disimpulkan bahwa penggunaan Buku Saku memberikan pengaruh yang lebih baik.

Kata kunci: Pengembangan model ADDIE dan Bahasa Arab 


\section{Pendahuluan}

Proses pembelajaran idealnya merupakan interaksi edukatif antara peserta didik dengan lingkungan belajarnya. Kegiatan pembelajaran perlu diarahkan untuk membantu peserta didik menguasai sekurang-kurangnya tingkat kompetensi minimal, agar mereka dapat dapat mencapai tujuan yang ditetapkan. Kreatifitas pendidik dalam mengelola aktifitas pembelajaran sangat membantu keberhasilan pencapaian tujuan pembelajaran tersebut.

Kualitas pendidikan tidak hanya dilihat dari sekadar penyelenggaraan pendidikan, tetapi pendidikan yang bermutu, baik dari sisi input, proses, dan output, maupun outcome. ${ }^{1}$ Input yang bermutu adalah tenaga pengajar yang bermutu, peserta didik yang bermutu, kurikulum yang bermutu dan berbagai aspek penyelenggaraan yang bermutu. Proses pendidikan yang bermutu adalah proses pembelajaran yang bermutu.

Proses belajar mengajar bahasa Arab selalu terkait dengan komponen-komponen yang ada di dalamnya. Komponen tersebut berupa peserta didik, guru, tujuan pembeelajaran, materi, metode, media dan evaluasi. $^{2}$ Karena pembelajaran adalah

${ }^{1}$ Tim Dosen Administrasi Pendidikan UPI, Manajemen Pendidikan (Cet. I; Bandung: Alfabet, 2009), h. 288

${ }^{2}$ Mudjiono Dimyati, Proses Belajar Mengajar, (Jakarta, Bumi Aksara: 2006), h. 23 merupakan suatu system, maka keberhasilan pembelajaran sangat ditentukan oleh sejauhmana efektifitas tiap-tiap komponen tersebut berinteraksi.

Media sebagai salah satu komponen dalam system itu, mempunyai fungsi sebagi sarana komunikasi non-verbal. Studi yang dilakukan British Audio Visual Association (1995) tentang persepsi murid memperkirakan bahwa sekitar 75\% kesan dapat diterima melalui indra sentuhan dan rabaan, $6 \%$ dari indra penciuman dan ras. Kalau belajar hanya dengan membaca saja maka pengetahuan yang mengendap hanya sekitar $10 \%$, dan jika hanya melalui pendengaran saja mengendapnya berkisar 20\%. Jika dilakukan penggabungan dari keduanya, yakni melihat dan mendengar, maka pengendapan pengetahuan berkisar 50\%. Mengalami sendiri dan mengulang pada kesempatan lain pengetahuan yang mengendap bias mencapai 90\%. Mengalami sendiri melalui media tingkat pengendapannya bias mencapai $80 \%$. ${ }^{3}$ Dari pernyataan Malapu maka lebih menegaskan lagi jika media mempunyai peranan yang sangat penting dalam keberhasilan pembelajaran intensifikasi bahasa Arab.

IAIN Metro memiliki visi "Menjadi Perguruan Tinggi Agama Islam yang Inovatif dalam sinergi sosio-ecotechno-preuneurship

\footnotetext{
${ }^{3}$ Syahrun Malapu, Profesionalisme Guru dalam Upaya Peningkatan Potensi Peserta Didik. Mutu Vol VII No 2. Edisi Juli-Desember 1998. (Jakarta: Dirjen Pendidikan Dasar dan Menengah Depdikbud, 1998)
} 
berlandaskan nilai-nilai keislaman dan keindonesiaan. Hal ini berarti bahwa pelaksanaan tri dharma perguruan tinggi (pendidikan, penelitian dan pengabdian pada masyarakat) di IAIN Metro bertujuan untuk menghasilkan lulusan yang bermutu dan berkompeten dalam berbagai bidang, satu diantaranya adalah kompetensi bahasa Arab sebagai bahasa komunikasi internasional juga sebagai ilmu pengetahuan modern.

Sejalan dengan visi dan misi IAIN Metro, Unit Pengembangan Bahasa (UPB) mempunyai visi dan misi yang salah satunya adalah pengembangan kompetensi kebahasaan, yaitu bahasa Arab dan bahasa Inggris, untuk mengembangkan kopetensi kebahasaan tersebut, terutama bahasa Arab, langkah kongkret yang dilaksanakan oleh UPB IAIN Metro adalah dengan kegiatan Intensifikasi bahasa Arab bagi mahasiswanya.

Pada pelaksanaan pembelajarannya, UPB IAIN Metro membagikan Buku Saku kepada dosen/tutor dan seluruh mahasiswa yang mengikuti intensifikasi bahasa Arab. Buku saku adalah buku berukuran kecil yang dapat dimasukkan ke dalam saku dan mudah dibawa ke mana-mana. ${ }^{4}$ Buku Saku tersebut berisi materi-materi yang diharapkan dapat dikuasai mahasiswa selama

${ }^{4}$ Departemen Pendidikan Nasional, Kamus Besar Bahasa Indonesia Pusat Bahasa Edisi Keempat (Jakarta: Gramedia Pustaka Utama, 2012) h. 218 pembelajaran intensifikasi bahasa Arab.

Sejak pertama kali dicetak dan digunakan pada pembelajaran intensifikasi bahasa Arab di IAIN Metro. Buku saku tersebut belum pernah direvisi pada contentnya, sehingga harus dilakukan pengembangan bahan ajar intensifikasi agar atmosfir pembelajaran intensifikasi menjadi semakin segar dan tujuan intensifikasi bahasa Arab di IAIN Metro dapat tercapai dengan maksimal.

\section{Hasil Penelitian dan Pembahasan}

\section{Pengembangan Model ADDIE}

Model pengembangan diartikan sebagai proses desain konseptual dalam upaya peningkatan fungsi dari model yang telah ada sebelumnya, melalu penambahan komponen pembelajaran yang dianggap dapat meningkatkan kualitas pencapaian tujuan. ${ }^{5}$ Pengembangan model dapat diartikan sebagai upaya memperluas untuk membawa suatu keadaan atau situasi secara berjenjang kepada situasi yang lebih sempurna atau lebih lengkap maupun keadaan yang lebih baik. Pengembangan model ADDIE merupakan salah satu model desain pembelajaran yang sifatnya lebih efesien dan generik. Pengembangan ini muncul pada tahun 1990-an yang dikembangkan oleh Reiser dan Mollenda. Salah

\footnotetext{
${ }^{5}$ Sugiarta \& Awandi Nopyan, Pengembangan Model Pengelolaan Program Pembelajaran Kolaboratif untuk Kemandirian Anak Jalanan di Rumah Singgah (Studi Berfokus di Rumah Singgah Kota Bekasi). Program Pascasarjana UPI Bandung. Desertasi tidak dipublikasikan, 2007. h.11
} 
satu fungsinya, ADDIE menjadi pedoman dalam membangun perangkat dan infrastruktur program pelatihan yang efektif, dinamis dan mendukung kinerja pelatihan itu sendiri. Model ADDIE adalah istilah sehari-hari yang digunakan untuk menggambarkan pendekatan sistematis untuk mengembangak pembeajaran. ${ }^{6}$ Desain Model ADDIE merupkan desain tentang tahapan-tahapan yang mengacu pada Analysis, (analisis), Design (desain), Development (pengembangan), Implementation (implementasi) dan Evaluation (Evaluasi). ${ }^{7}$

\section{Tahap Pengembanagan Model Addie}

Tahapan yang digunakan dalam penelitian dan pengembangan ini menggunakan model ADDIE yang dikembangkan oleh Dick and Carry Dick and Carry sebagai berikut: ${ }^{8}$

${ }^{6}$ Molenda M, In Search of the ellusive ADDIE model. Pervormance improvement, 42 (5), 34-36 Submitetted for publication in A.Kovalchick \& K Dawson, Ed's, Educational Technologi: An Encyclopedia. Copyright by ABC-Clio, Santa Barbara, CA, 2003 (http://www.indian.edi) diakses pada 25 Maret 2016.

${ }^{7}$ Branch R.M, Instructional Design: The ADDIE Approach (New York: Springer, 2009) h. 20

${ }^{8}$ Endang Mulyatiningsih, Riset Terapan Bidang Pendidikan dan Teknik, (Yogyakarta: UNY Press, 2011) h.183

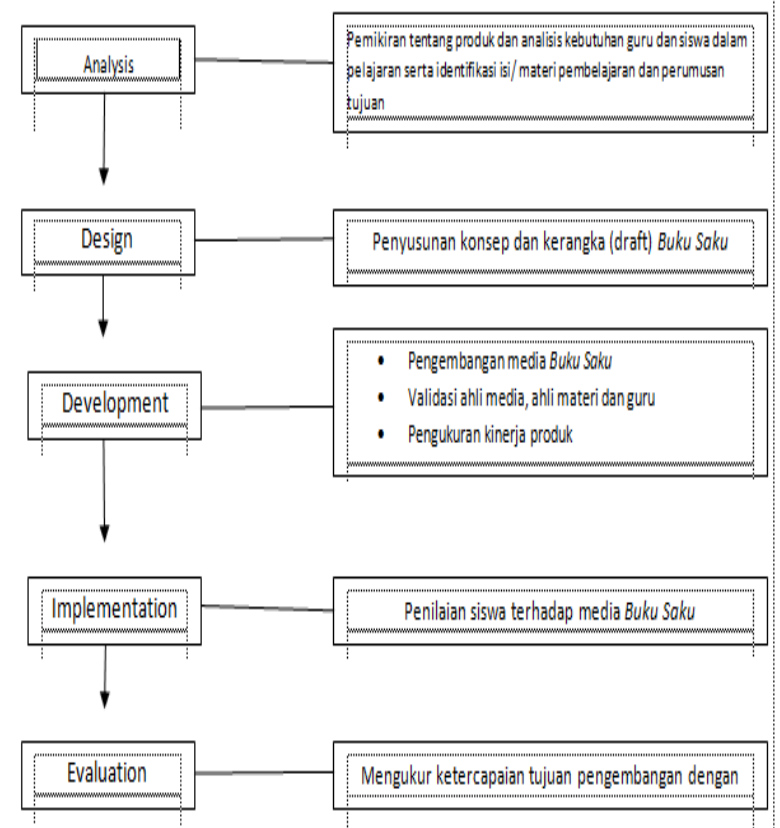

Gambar 1. Prosedur Pengembangan Media Buku Saku Model ADDIE

\section{a. Tahap Analisis (Analysis)}

Dalam menyusun sebuah bahan ajar, maka perlu melakukan penelusuran karakteristik peserta didik terkait identitasnya, budaya, gaya belajar, kemampuan berbahasa, kondisi keluarga, intelejensi, kesiapan belajar, bakat, dan karakteristik personal lainnya, lalu menggunakan informasi-informasi ini sebagai need analysis dalam menyiapkan bahan ajar atau segala sesuatu yang terkait dengan upaya keberhasilan sebuah pembelajaran lalu disinergikan ke dalam strategi pembelajaran, serta mampu memahami dan melayani peserta didik dalam belajar. ${ }^{9}$ Maka dari itu, dalam penyusunan buku saku ini akan dilakukan analisis kebutuhan dan karakterisitik, serta analisis kompetensi dan intruksional.

${ }^{9}$ William Powwel and Ochan Kusuma, How to Teach Now (Virginia: ASDC, 2011) h. 8 
1) Analisis kebutuhan dan Karakteristik Mahamahasiswa

Peserta intensifikasi bahasa Arab di IAIN Metro adalah mahamahasiswa semester I (satu) yang terdiri dari berbagai jurusan, sebagian besar dari mereka belum pernah belajar bahasa Arab, maka dari itu hetrogenitas karakteristik mahasiswa ini harus menjadi perhitungan dalam menyusun buku saku yang dikembangkan. Merujuk dari karakteristik dan kemampuan dasar berbahasa Arab mahasiswa tersebut, maka materi yang dibuat dalam Buku Saku ini nantinya adalah materi-materi dasar berupa percakapan ringan yang disertai dengan kamus penunjang.

\section{2) Analisis Kompetensi dan Intruksional}

Analisis ini diperlukan untuk mengurai kompetensi umum pembelajaran bahasa Arab menjadi sejumlah sub kompetensi. Dick and Carey mendifinisikan proses intruksional ini sebagai:....the procedure applied to instructional goal in order to indentify the relevan skills and their sybordinate skills and information required for a student to achive the goal"10 Kompetensi dan Intruksional berkaitan dengan Standar Kompetensi (SK) dan Kompetensi Dasar (KD) yang akan dimuat dalam Buku Saku.

\footnotetext{
${ }^{10}$ Dick W.Carey, L And Carey.J.O, The Systematic Design of Intruction, Colombus, Ohio: Pearson, 2009), h.381
}

Pada tahap analisis kompetensi, dilakukan kajian terhadap kompetensi minimal yang harus dicapai mahasiswa sesuai dengan standar isi yang ditetapkan oleh Badan Standar Nasional Pendidikan (BSNP). Materi yang menekankan pada keterampilan berbicara dilakukan dengan mengungkapkan informasi secara lisan dalam bentuk paparan atau dialog sederhana sesuai dengan Standar Kompetensi (SK) yang dijabarkan dalam bentuk hiwar dan paparan dialog, serta Kompetensi Dasar (KD) yaitu menyampaikan informasi secara lisan dengan lafal yang tepat dalam kalimat sederhana serta melakukan dialog sederhana dengan lancar yang mencerminkan kecakapan berkomunikasi dengan santun dan tepat.

\section{b. Tahap Perancangan (Design)}

Tahap desain merupakan tahap perancangan media yang meliputi pembuatan desain media secara keseluruhan. Mulai dari penyusunan materi, memilih gambar, menyusun soal-soal pelatihan dan segala hal yang akan dimuat dalam Buku Saku.

Buku Saku yang dikembangkan dirancang dengan tampilan yang menarik dengan pemilihan gambar yang sesuai dengan materi yang diajarkan. Dalam Buku Saku ini disertakan pula soal-soal latihan untuk mengukur pemahaman mahasiswa terhadap materi yang diajarkan dan kamus penunjang untuk memudahkan mahasiswa saat menggunakannya. Peneliti memilih 
materi berupa hiwar (percakapan) dengan tema yang berkaitan dengan kehidupan sehari-hari dan budaya di Indonesia.

Berdasarkan tahap pertama, yaitu analisisi, maka diperoleh rancangan produk Buku Saku sebagai berikut:

\section{c. Pembuatan Produk (Development)}

1) Pembuatan Draft Buku Saku

Pada tahap development ini, Buku Saku diproduksi untuk proses pembelajaran. Pada tahapan pengembangan ini pula semua materi yang telah dikumpulkn akan dituangkan dalam Buku Saku yang disusun menggunakan microsoft word. Componen dirangkai menjadi satu kesatuan sesuai desain yang telah dibuat sebelumny. Cover dan bagian belakang buku disusun menggunakan program Corel Draw. Materi disajikan secara ringkas dengan ilustrasi yang menarik.

Langkah pertama yang dilakukan adalah dengan membuat cover mentah Buku Saku, Setelah itu rangkaian isi Buku Saku disusun berurutan, mulai dari bagian awal Buku Saku yang terdiri dar kata pengantar, standar kompetensi dan kompetensi dasar, daftar isi, lalu bagian isi pcket book yang berupa materi-materi yang terdiri dari tiga bagian, yaitu ungkapan-ungkapan harian, percakapan dan kamus penunjang, lalu bagian akhir yaitu diisi dengan sumber rujukan atau daftar pustaka.

\section{2) Validasi Buku Saku}

Setelah draft Buku Saku tersusun, selanjutnya Buku Saku akan melalui tahap validasi. Pada tahap ini Buku Saku divalidasi oleh ahli materi dan ahli media. Ahli Materi dan Media boleh berjumlah satu orang, namun akan lebih baik lagi jika divalidasi oleh lebih dari satu orang. Pada tahap ini, validasi juga dilakukan kepada pengajar intensifikasi, karena para pengajar lebih paham keadaan dan tantangan yang sesungguhnya di kelas.

Hasil validasi inilah yang kemudian dijadikan acuan perbaikkan atau revisi pada draft Buku Saku sehingga nantinya menjadi Buku Saku yang layak dan siap untuk diujicobakan

\section{d. Tahap Implementasi (Implementation)}

Pada tahap ini dimplementasikan rancangan dan metode yang telah dikembangkan pada situasi yang nyata yaitu di kelas. Artinya pada tahap ini, produk yang dibuat diujikan kepada mahasisiswa dalam kelompok kecil kemudian dievaluasi dan direvisi. Kemudian uji coba dapat dilakukan pada kelompok besar kemudian dievaluasi kembali dan direvisi sehingga menghasilkan produk akhir yang siap didiseminasikan. 
Tujuan dari tahap ini adalah untuk mengetahui respon mahasiswa terhadap media Buku Saku.Implementasi dilakukan dalam beberapa kali pertemuan.

Pada pertemuan pertama, kegiatan pembelajaran dilakukan dengan pemberian pre tes. Pemberian pre tes ini dimaksudkan untuk mengetahui sejauh mana pengetahuan mahamahasiswa tentang materimateri yang akan dipelajari pada intensifikasi bahasa Arab. Hal tersebut dapat diketahui setelah menganalisis hasil jawaban mahamahasiswa sehingga diperoleh nilai pretes mahamahasiswa.

Pada pertemuan kedua dan pertemuan-pertemuan seterusnya materi yang sudah dibuat dalam draft Buku Saku mulai diajarkan kepada mahasiswa dalam skala kecil dan besar. Dalam satu sesi pertemuan, dilakukan evaluasi materi yang diajarkan. Evaluasi pada pertemuan kedua ini dilakukan secara lisan. Pertanyaan secara lisan ini dilakukan dengan dua cara, yang pertama, pertanyaan yang diajukan dijawab oleh seluruh mahamahasiswa secara bersama-sama, kmudian yang kedua, pertanyaan yang diajukan harus dijawab oleh mahasiswamahasiswa yang ditunjuk oleh tutor.

Pada pertemuan terakhir, mahasiswa diminta untuk mengerjakan postes dan mengisi angket tanggapan mahasiswa. Nilai postes ini digunakan untuk mengetahui hasil belajar mahamahasiswa selama menggunakan draft poket book yang telah dirancang. Nilai postes ini nantinya akan dibandingkan dengan nilai pretes sehingga diketahui ada tidaknya peningkatan hasil belajar.

\section{e. Evaluasi (Evaluation)}

Evaluasi adalah tahap kelima dalam proses pengembangan model ADDIE. Evaluasi adalah proses yang dilakukan untuk menentukan nilai, harga dan manfaat dari suatu objek. ${ }^{11}$

Pada tahap ini, dilakukan evaluasi terhadap produk Buku Saku secara keseluruhan sebelum menjadi produk akhir. Tahap ini dijadikan dasar untuk meningkatkan kualitas produk di kemudian hari. Tahap-tahap yang ditempuh dalam evaluasi ini adalah:

1) Memberikan angketrespon kepada mahasiswa untuk memberikan komentar dan saran tentang media Buku Saku.

2) Analisis hasil angket yang telah dibagikan untuk menyempurnakan produk sebelum disebarluaskan.

3) Kelayakan Buku Saku

\section{a. Ahli Materi}

Validitas yang dilakukan kepada ahli materi adalah dengan mengumpulkan saran dan pendapat dari ahli materi untuk

\footnotetext{
${ }^{11}$ Stufflebeam, D.M Shunkfield, A.J. Evaluation Theory: Models and Aplications, (USA: Jossey Bass, 2007) h. 32
} 
melakukan revisi. Penilaian Buku Saku ahli materi dapat dilihat pada tabel berikut

Tabel 1

Hasil Penilaian oleh Ahli Materi

\begin{tabular}{|c|c|c|c|}
\hline No & Indikator & Nilai & Kreteria \\
\hline \multicolumn{4}{|c|}{ Aspek Relevansi materi } \\
\hline 1 & $\begin{array}{l}\text { Kesesuaian materi } \\
\text { dengan kompetensi dasar } \\
\text { dan Standar Kompetensi }\end{array}$ & 5,00 & Sangat baik \\
\hline 2 & $\begin{array}{l}\text { Kesesuaian materi } \\
\text { dengan tujuan } \\
\text { pembelajaran }\end{array}$ & 4,00 & Baik \\
\hline 3 & $\begin{array}{l}\text { Kebenaran konsep materi } \\
\text { ditinjau dari aspek } \\
\text { keilmuan }\end{array}$ & 4,00 & Baik \\
\hline \multicolumn{4}{|c|}{ spek Pengorganisiran Materi } \\
\hline 1 & $\begin{array}{l}\text { Kejelasan penyampaian } \\
\text { materi }\end{array}$ & 4,00 & Baik \\
\hline 2 & $\begin{array}{l}\text { Sistematika } \\
\text { penyampaian materi }\end{array}$ & 5,00 & Sangat Baik \\
\hline 3 & Kemenarikan materi & 5,00 & Sangat Baik \\
\hline 4 & Aktualitas materi & 5,00 & Sangat Baik \\
\hline 5 & $\begin{array}{l}\text { Kesesuaian tingkat } \\
\text { kesulitan dengan } \\
\text { keabstrakan konsep }\end{array}$ & 4,00 & Baik \\
\hline 6 & $\begin{array}{l}\text { Sistematika penyajian } \\
\text { logis }\end{array}$ & 5,00 & Sangat Baik \\
\hline 7 & $\begin{array}{l}\text { Ketepatan pemilihan } \\
\text { materi }\end{array}$ & 5,00 & Sangat Baik \\
\hline 8 & Daya guna materi & 5,00 & Sangat Baik \\
\hline 9 & Keakuratan konsep & 4,00 & Baik \\
\hline \multicolumn{4}{|c|}{ Aspek Bahasa } \\
\hline 1 & $\begin{array}{l}\text { Kejelasan penggunaan } \\
\text { kata dan bahasa }\end{array}$ & 5,00 & Sangat Baik \\
\hline 2 & $\begin{array}{l}\text { Kesesuaian penggunaan } \\
\text { kalimat }\end{array}$ & 4,00 & Baik \\
\hline 3 & $\begin{array}{l}\text { Penggunaan bahasa yang } \\
\text { komunikatif }\end{array}$ & 5,00 & Sangat Baik \\
\hline 4 & $\begin{array}{l}\text { Kemudahan kalimat } \\
\text { untuk dipahami }\end{array}$ & 5,00 & Sangat Baik \\
\hline 5 & $\begin{array}{l}\text { Ketepatan tata bahasa } \\
\text { dan istilah }\end{array}$ & 4,00 & Baik \\
\hline \multicolumn{4}{|c|}{$\begin{array}{l}\text { Aspek ategi Belajar bagi Strategi Belajar Bahasa } \\
\text { Arab }\end{array}$} \\
\hline 1 & $\begin{array}{l}\text { Kemampuan mendorong } \\
\text { rasa ingin tahu } \\
\text { mahamahasiswa }\end{array}$ & 5,00 & Sangat Baik \\
\hline 2 & $\begin{array}{l}\text { Dukungan Buku Saku } \\
\text { bagi kemandirian belajar } \\
\text { mahamahasiswa }\end{array}$ & 5,00 & Sangat Baik \\
\hline 3 & $\begin{array}{l}\text { Kemampuan Buku Saku } \\
\text { menambah pengetahuan }\end{array}$ & 5,00 & Sangat Baik \\
\hline 4 & $\begin{array}{l}\text { Kemampuan Buku Saku } \\
\text { dalam meningkatkan } \\
\text { pemahaman } \\
\text { mahamahasiswa }\end{array}$ & 5,00 & Sangat Baik \\
\hline
\end{tabular}

\begin{tabular}{|c|c|c|c|}
\hline 5 & $\begin{array}{l}\text { Kemampuan Buku Saku } \\
\text { dalam menambah } \\
\text { motivasi belajar } \\
\text { mahamahasiswa } \\
\end{array}$ & 5,00 & Sangat Baik \\
\hline \multicolumn{4}{|c|}{ Aspek Kemanfaatan } \\
\hline 1 & Fungsi gambar & 5,00 & Sangat Baik \\
\hline 2 & $\begin{array}{l}\text { Kesesuaian gambar } \\
\text { dengan materi }\end{array}$ & 5,00 & Sangat Baik \\
\hline 3 & Kemenarikan table & 5,00 & Sangat Baik \\
\hline 4 & $\begin{array}{l}\text { Penggunaan Buku Saku } \\
\text { tidak terikat waktu }\end{array}$ & 5,00 & Sangat Baik \\
\hline & Nilai Total & 3,00 & Sangat Baik \\
\hline & Nilai Rata-rata & & Sangat Baik \\
\hline & Presentase & $62 \%$ & \\
\hline
\end{tabular}

Sumber: Data primer yang diolah

Berdasarkan penilaian oleh ahli materi secara keseluruhan, Buku Saku Kutaibu Al Lughah Al Arabiyah As Saidah Lilmubtadiin mendapatkan nilai total 123,00 pada 26 indikator sehingga termasuk kategori sangat baik. Apabila dihitung dengan presentase, Buku Saku Kutaibu Al Lughah Al Arabiyah As Saidah Lilmubtadiin mendapatkan nilai 94,62\% sehingga termasuk dalam kategori sangat layak digunakan sebagai bahan ajar.

Selain analisis nilai keseluruhan, dapat diketahui pula penilaian Buku Saku Kutaibu Al Lughah Al Arabiyah As Saidah Lilmubtadiin ini jika dilihat dari masingmasing aspek. Berikut disajikan analisis kelayakan untuk setiap aspek yang dinilai oleh ahli materi

\section{b. Ahli Media}

Validitas yang dilakukan kepada ahli materi adalah dengan mengumpulkan saran dan pendapat dari ahli materi untuk melakukan revisi. Penilaian Buku Saku Kutaibu Al Lughah Al Arabiyah As Saidah 
Lilmubtadiin oleh ahli media dapat dilihat pada tabel berikut

Tabel 2

Penilaian Analisis Kelayakan setiap Aspek oleh Ahli Media

\begin{tabular}{|c|c|c|c|}
\hline No & Indikator & Nilai & Kriteria \\
\hline \multicolumn{4}{|c|}{ Aspek Kelayakan Isi } \\
\hline 1 & $\begin{array}{l}\text { SK Tercantum secara } \\
\text { eksplisit }\end{array}$ & 5 & $\begin{array}{l}\text { Sangat } \\
\text { Baik }\end{array}$ \\
\hline 2 & $\begin{array}{l}\text { KD Tercantum secara } \\
\text { eksplisit }\end{array}$ & 5 & $\begin{array}{l}\text { Sangat } \\
\text { Baik }\end{array}$ \\
\hline 3 & $\begin{array}{l}\text { Kesesuaian isi buku } \\
\text { dengan SK dan KD }\end{array}$ & 4 & Baik \\
\hline & Jumlah & 14,00 & $\begin{array}{l}\text { Sangat } \\
\text { Baik }\end{array}$ \\
\hline & Nilai rata-rata & 4,66 & Sangat \\
\hline & Presentase & $93,33 \%$ & Layak \\
\hline \multicolumn{4}{|c|}{ Aspek Penyajian } \\
\hline 1 & Halaman judul & 4 & Baik \\
\hline 2 & Kata pengantar & 4 & Baik \\
\hline 3 & Daftar isi & 4 & Baik \\
\hline 4 & $\begin{array}{l}\text { Ungkapan-ungkapan } \\
\text { harian }\end{array}$ & 4 & Baik \\
\hline 5 & Percakapan sehari-hari & 4 & Baik \\
\hline 6 & Kamus penunjang & 4 & Baik \\
\hline 7 & Soal-soal latihan & 4 & Baik \\
\hline 8 & Daftar pustaka & 4 & Baik \\
\hline 9 & $\begin{array}{l}\text { Penyajian materi } \\
\text { sistematis dan logis }\end{array}$ & 4 & Baik \\
\hline 10 & $\begin{array}{l}\text { Keurutan penyajian } \\
\text { konsep }\end{array}$ & 4 & Baik \\
\hline 11 & $\begin{array}{l}\text { Penyajian gambar dan } \\
\text { table }\end{array}$ & 4 & Baik \\
\hline & Jumlah & 44,00 & Baik \\
\hline & Nilai rata-rata & 4 & Layak \\
\hline & Presentase & $80 \%$ & \\
\hline \multicolumn{4}{|c|}{ Aspek Bahasa } \\
\hline 1 & $\begin{array}{l}\text { Kejelasan penggunaan } \\
\text { kata dan bahasa }\end{array}$ & 4 & Baik \\
\hline 2 & $\begin{array}{l}\text { Kesesuaian penggunaan } \\
\text { kalimat }\end{array}$ & 4 & Baik \\
\hline 3 & $\begin{array}{l}\text { Penggunaan bahasa } \\
\text { yang komunikatif }\end{array}$ & 4 & Baik \\
\hline 4 & $\begin{array}{l}\text { Kemudahan kalimat } \\
\text { untuk dipahami }\end{array}$ & 4 & Baik \\
\hline 5 & $\begin{array}{l}\text { Ketepatan tata bahasa } \\
\text { dan istilah }\end{array}$ & 3 & Cukup \\
\hline & Jumlah & 19,00 & Baik \\
\hline & Nilai rata-rata & 3,8 & \multirow{2}{*}{ Layak } \\
\hline & Presentase & $76 \%$ & \\
\hline
\end{tabular}

\begin{tabular}{|c|c|c|}
\hline \multicolumn{3}{|c|}{$\begin{array}{c}\text { Aspek Efek bagi Strategi Pembelajaran Intensifikasi } \\
\text { Bahasa Arab }\end{array}$} \\
\hline \begin{tabular}{l|l}
1 & $\begin{array}{l}\text { Kemampuan } \\
\text { mendorong rasa ingin } \\
\text { tahu mahamahasiswa }\end{array}$ \\
\end{tabular} & 4 & Baik \\
\hline \begin{tabular}{l|l}
2 & $\begin{array}{l}\text { Kemampuan } \\
\text { merangsang motivasi }\end{array}$ \\
\end{tabular} & 4 & Baik \\
\hline \begin{tabular}{l|l}
3 & $\begin{array}{l}\text { Kemampuan media } \\
\text { menambah } \\
\text { pengetahuan }\end{array}$ \\
\end{tabular} & 5 & Sangat Baik \\
\hline Jumlah & 13,00 & Sangat Baik \\
\hline Nilai rata-rata & 4,33 & Sangat Layak \\
\hline Presentase & $86,66 \%$ & \\
\hline \multicolumn{3}{|c|}{ Aspek Kegrafikkan } \\
\hline \begin{tabular}{l|l}
1 & Kulit Buku Saku \\
\end{tabular} & 4 & Baik \\
\hline \begin{tabular}{l|l}
2 & Isi Buku Saku \\
\end{tabular} & 4 & Baik \\
\hline \begin{tabular}{l|l}
3 & Keterbacaan \\
\end{tabular} & 3 & Cukup \\
\hline 4 itas cetakkan & 4 & Baik \\
\hline \begin{tabular}{l|l}
5 & Kekuatan fisik Buku \\
Saku
\end{tabular} & 4 & Baik \\
\hline \begin{tabular}{l|l}
6 & $\begin{array}{l}\text { Kesesuaian pemilihan } \\
\text { warna }\end{array}$
\end{tabular} & 3 & Cukup \\
\hline $7 \begin{array}{l}\text { Kesesuaian pemilihan } \\
\text { jenis huruf }\end{array}$ & 4 & Baik \\
\hline $8 \begin{array}{l}\text { Kesesuaian pemilihan } \\
\text { ukuran huruf }\end{array}$ & 4 & Baik \\
\hline $\begin{array}{ll}9 & \begin{array}{l}\text { Kesesuaan gambar } \\
\text { dengan materi }\end{array} \\
\end{array}$ & 4 & Baik \\
\hline $10 \begin{array}{l}\text { Keseimbangan } \\
\text { proporsi gambar }\end{array}$ & 4 & Baik \\
\hline 11 Kemenarikan desain & 4 & Baik \\
\hline \begin{tabular}{l|l}
12 & Kelengkapan struktur \\
Buku Saku
\end{tabular} & 4 & Baik \\
\hline $13 \begin{array}{l}\text { Judul Buku Saku sesuai } \\
\text { dengan materi } \\
\text { pembelajaran }\end{array}$ & 4 & Baik \\
\hline Jumlah & 50,00 & Baik \\
\hline Nilai rata-rata & 3,84 & Layak \\
\hline Presentase & $6,92 \%$ & \\
\hline
\end{tabular}

Sumber: Data primer yang diolah

Berdasarkan tabel di atas, pada aspek kelayakan isi dengan 3 indikator mendapatkan nilai 14,00 sehingga termasuk dalam kategori sangat baik. Kelayakan Buku Saku termasuk dalam kategori sangat layak dengan presentase yang diperoleh $93,33 \%$.

Pada aspek penyajian dengan 11 indikator mendapatkan nilai 44,00 sehingga termasuk dalam kategori baik. Kelayakan Buku Saku termasuk dalam kategori layak 
dengan presentase yang diperoleh $80 \%$.

Pada aspek Bahasa dengan 5 indikator mendapatkan nilai 19,00 sehingga termasuk dalam kategori baik. Kelayakan Buku Saku termasuk dalam kategori layak dengan presentase yang diperoleh $76 \%$.

Pada aspek Strategi belajar bahasa Arab dengan 3 indikator dapatkan nilai 13,00 sehingga termasuk dalam kategori sangat baik. Kelayakan Buku Saku termasuk dalam kategori sangat layak dengan presentase yang diperoleh $86,66 \%$.

Pada aspek kegrafikkan dengan 13 indikator dapatkan nilai 50,00 sehingga termasuk dalam kategori baik. Kelayakan Buku Saku termasuk dalam kategori layak dengan presentase yang diperoleh $76,92 \%$.

\section{Pengukuran Ketercapaian Pembelajaran terhadap Produk yang dikembangkan.}

Untuk mengukur ketercapaian pembelajaran dari Buku Saku Kutaibu Al Lughah Al Arabiyah As Saidah Lilmubtadiin akan dilakukan perngitungan nilai dari kelas yang selama pembelajaran menggunakan Buku Saku yang dikembangkan ( Kelas C.21) dengan kelas yang selama proses pembelajaran menggunakan buku lama (C.22), maka akan dilakukan bberapa tahap, yaitu:

\section{a. Uji Reliabelitas}

Reliability Statistics

\begin{tabular}{|c|c|}
\hline Cronbach's Alpha & N of Items \\
\hline .298 & 50 \\
\hline
\end{tabular}

$$
\alpha=0,05
$$

Berdasarkan hasil analisis dengan SPSS diperoleh bahwa nilai Reliabilitas Alpha Cronbach $=0,298$ dan lebih besar dari $\alpha=0,05$ maka instrumen poket tersebut reliabel (dapat dipercaya).

\section{b. Uji Anova}

1) Hipotesis Uji Normalita $\mathrm{H}_{0}: \mu_{1}=\mu_{2}$ $\mathrm{H}_{0}: \mu_{1} \neq \mu_{2}$

a) $\alpha=0,05$

b) Statistik Uji: Uji Lilliefors dengan SPSS

c) Hasil Uji analisis SPSS

\section{ANOVA}

\begin{tabular}{|l|c|c|c|c|c|}
\hline NILAI & & & & & \\
\hline & $\begin{array}{l}\text { Sum of } \\
\text { Squares }\end{array}$ & df & $\begin{array}{c}\text { Mean } \\
\text { Square }\end{array}$ & F & Sig. \\
\hline $\begin{array}{l}\text { Between } \\
\text { Groups } \\
\text { Within } \\
\text { Groups } \\
\text { Total }\end{array}$ & 432.180 & 1 & 432.180 & 4.691 & 0.035 \\
\hline
\end{tabular}

2) Keputusan Uji

$\mathrm{F}_{\text {hitung }}=4,691$ dan $\mathrm{F}_{\text {tabel }}=4,08$

Berdasarkan hasil analisis tersebut diperoleh bahwa nilai $F_{\text {hitung }}$ lebih besar dari $\mathrm{F}_{\text {tabel }}$ maka $\mathrm{H}_{0}$ ditolak dan $\mathrm{H}_{1}$ diterima 
3) Kesimpulan Uji

Rata-rata nilai hasil test pada kelas yang menggunakan Buku Saku Kutaibu Al Lughah Al Arabiyah As Saidah Lilmubtadiin berbeda dengan kelas yang menggunakan Buku Saku yang lama.

\section{c. Uji Lanjut Anava}

Descriptives

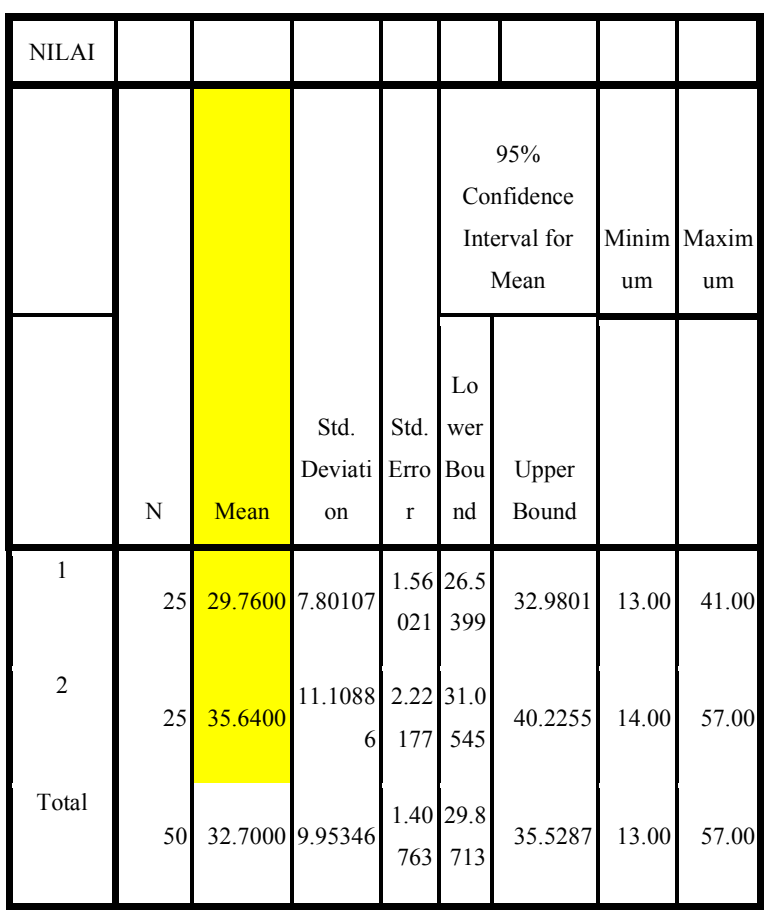

Berdasarkan hasil analisis tersebut, diperoleh data bahwa rata-rata nilai pada kelas yang menggunakan Buku Saku Kutaibu Al Lughah Al Arabiyah As Saidah Lilmubtadiin lebih besar dari rata2 nilai kelas yang menggunakan Buku Saku yang lama, sehingga penggunaan pocket memberikan pengaruh yang lebih baik.

\section{d. Kesimpulan Uji F}

Berdasarkan analisis dari Uji Lilliefors dengan SPSS diperoleh data $F_{\text {hitung }}$ sebesar 4,691.
Untuk menghitung presentase signifikasi pergerakan pembelajaran menggunakan Desain Buku Saku yang dikembangkan digunakan rumus sebagai berikut:

$$
\begin{aligned}
& F_{\text {hitung }} \times 100 \\
& =46,91 \\
& =47 \%
\end{aligned}
$$

Dari perhitungan di atas, dapat disimpulkan bahwa bahwa signifikasi pergerakan pembelajaran menggunakan Buku Saku yang dikembangkan adalah sebesar $47 \%$.

\section{Kesimpulan}

Setelah data dianalisa dan dikaji, dalam penelitian pengembangan ini diperoleh kesimpulan bahwa angkah-langkah mengembangkan buku saku bahasa Arab yaitu dengan langkah berikut ini: a) Analysis, merupakan tahap awal berupa analisis kebutuhan mahasiswa dan perumusan kompetensi belajar. b) Design, merupakan tahapan perancangan produk yang terdiri dari penyusunan draft Buku Saku tahap I.c) Development, merupakan tahap memproduksi yang dimulai dari pencetakkan Buku Saku, instrumen penilaian, Validasi Ahli, revisi, dan pencetakkan draft Buku Saku tahap II. d) Implementation, merupakan tahap uji coba Buku Saku terhadap subjek uji coba lapangan. e) Evaluation, merupakan tahap akhir dari prosedur pengembangan produk berupa ketercapaian belajar mahasiswa. 
Uji kelayakan dari Ahli Materi diperoleh nilai total 123,00 pada 26 indikator dengan prosentase nila 94,62\% sehingga termasuk kategori sangat baik. Uji kelayakan dari Ahli Media diperoleh nilai total 138,00 pada 35 indikator dengan prosentase $78,85 \%$ sehingga termasuk kategori baik. Berdasarkan Uji Kelayakan dari para Ahli tersebut dapat disimpulkan jika Buku Saku Kutaibu Al Lughah Al Arabiyah As Saidah Lilmubtadiin termasuk dalam kategori sangat layak digunakan.

Berdasarkan hasil analisis menggunakan Analisis Varian (Anova), diperoleh data bahawa Mean pada kelas yang diajar menggunakan Buku Saku yang dikembangkan lebih besar dari pada Mean pada kelas yang diajarkan menggunakan buku yang sudah ada sebelumnya, yaitu 35,64 dan 29, 76, sehingga dapat disimpulkan jika penggunaan Buku Saku memberikan pengaruh yang lebih baik. Hasil analisis dari Uji Lilliefors dengan SPSS diperoleh data $F_{\text {hitung }}$ sebesar 4,691, maka dapat diketahui bahwa signifikasi pergerakan pembelajaran menggunakan Buku Saku yang dikembangkan adalah sebesar $47 \%$.

\section{Daftar Pustaka}

Branch R.M, Instructional Design: The ADDIE Approach (New York: Springer, 2009)
Departemen Pendidikan Nasional, Kamus Besar Bahasa Indonesia Pusat Bahasa Edisi Keempat (Jakarta: Gramedia Pustaka Utama, 2012)

Dick W.Carey, L And Carey.J.O, The Systematic Design of Intruction, Colombus, Ohio: Pearson, 2009)

Endang Mulyatiningsih, Riset Terapan Bidang Pendidikan dan Teknik, (Yogyakarta: UNY Press, 2011)

Molenda M, In Search of the ellusive ADDIE model. Pervormance improvement, 42 (5), 34-36 Submitetted for publication in A.Kovalchick \& K Dawson, Ed's, Educational Technologi: An Encyclopedia. Copyright by ABC-Clio, Santa Barbara, CA, 2003 (http://www.indian.edi) diakses pada 25 Maret 2016.

Mudjiono Dimyati, Proses Belajar Mengajar, (Jakarta, Bumi Aksara: 2006

Stufflebeam, D.M Shunkfield, A.J. Evaluation Theory: Models and Aplications, (USA: Jossey Bass, 2007)

Sugiarta \& Awandi Nopyan, Pengembangan Model Pengelolaan Program Pembelajaran Kolaboratif untuk Kemandirian Anak Jalanan di Rumah Singgah (Studi Berfokus di Rumah Singgah Kota Bekasi). Program Pascasarjana UPI Bandung. Desertasi tidak dipublikasikan, 2007.

Syahrun Malapu, Profesionalisme Guru dalam Upaya Peningkatan Potensi Peserta Didik. Mutu Vol VII No 2. Edisi Juli-Desember 1998. (Jakarta: Dirjen Pendidikan Dasar dan Menengah Depdikbud, 1998)

Tim Dosen Administrasi Pendidikan UPI, Manajemen Pendidikan (Cet. I; Bandung: Alfabet, 2009)

William Powwel and Ochan Kusuma, How to Teach Now (Virginia: ASDC, 2011) 